\title{
Purposes and Challenges of Integrating ICT in English Language Teaching in Nepalese Context
}

\author{
Prakash Bhattarai \\ Tribhuvan University, Kathmandu, Nepal \\ prakash.766671@gse.tu.edu.np
}

\begin{abstract}
Received : 2021-09-16
Revised : 2021-11-22

Accepted : 2021-11-23
\end{abstract}

ARTICLE HISTORY

\section{KEYWORDS}

\section{$I C T$}

$E L T$

Language Development

Motivation

Learner Autonomy

Challenges

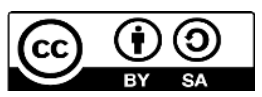

\begin{abstract}
This phenomenological study explores how English language teachers become information and communication technology (ICT) literate and why they make use of ICT in English language class and to find out the challenges in integrating ICT in English language teaching (ELT). For this purpose, two secondary-level English teachers were selected purposively, and in-depth interviews were conducted to collect data. The collected data were analyzed using the thematic analysis technique. The findings drawn from the lived experience of the teachers reveal that teachers become ICT literate and updated by taking formal classes, training, and teaching their students; they make use of ICT in ELT for students' language development, motivation, and autonomy. The challenge of keeping the students on the right track is the major challenge English language teachers encounter while integrating ICT in ELT. Though there are challenges, every English language teacher should try to teach the English language integrating ICT.
\end{abstract}

\section{Introduction}

Information and communication technology (ICT) has impacted every aspect of human life, from which the education sector in general and teaching-learning activities, in particular, cannot be an exception. In other words, as in other sectors, ICT has been widely used in teaching-learning activities. Defining ICT, Hafifah (2019, p. 21) states, "Information and communication technology, or ICT, is defined as the activities of using technologies, such as; computer, internet, and other telecommunications media (radio, $\mathrm{TV}$, smart-phones) to communicate, create and disseminate, store and manage information," and ICT in education means teaching and learning by the use of different ICT devices. ICTs are being used in education to support students to learn more effectively by providing teachers with access to a wide range of new pedagogy (Dhital, 2018).

The use of ICTs in education has changed several factors like pedagogy, student-teacher relationship, the concept of literacy, and students' learning achievement. Students and teachers who were only exposed to traditional ways of teaching-learning activities have shifted their way of teaching and learning. Students can compete in this global market. ICT in education has a multiplier effect throughout the education system, by enhancing learning and providing students with new sets of skills; by reaching students with poor or no access (especially those in rural and remote regions); by facilitating and improving the training of teachers; and by minimizing costs associated with the delivery of traditional instruction (UNESCO, 2014).

Different policy-related documents in Nepal i.e., National Information and Communication Technology Policy (ICT Policy, 2015), School Sector Development Plan (SSDP 2016- 2023), and 15th Plan (2019), focus on the use of ICT in education. These documents suggest empowering schools and teachers to make them ICT-friendly. In other words, they focus on infrastructure development and teacher training to integrate ICT in education. One of the objectives related to ICT of SSDP, 2016- 2023 is to improve classroom delivery by establishing an ICT enabling learning environment (including the institutional and professional capacity of managers and implementers) and based on need and context (Ministry of Education [MoE], 2016).

Similarly, ICT Policy, 2015 aims to integrate computer skills into the teaching and learning process at primary, high school, and tertiary levels. (Ministry of Information and Communication [MoIaC], 2015). From these lines, it is clear that ICT-related policies and documents emphasize the use of ICT in education in the Nepalese context. For the use, it is essential to make schools and teachers ICT friendly via infrastructure development and training, respectively. Integration of ICT in education is not only the focus of policy-related documents but also of the general 
public and all the stakeholders of education in Nepal. In line with this, Poudel (2015) mentions that there is a huge demand from the general public to integrate ICT in classroom instruction in the present context. For the integration, service-providing institutions should create ICT-friendly teaching and learning.

The integration of ICT with education in general and ELT, in particular, is both an opportunity and challenge for English language teachers. Opportunity in the sense that it makes teachers use modern student-centered strategies on the one hand and teach different language skills and aspects effectively on the other. Challenge in the sense of teachers facing some problems in the course of integrating ICT in ELT. Several studies have been conducted so far to explore the reasons, opportunities, and challenges of integrating ICT in ELT but very few of such studies have focused on secondary level English language teachers' lived experience on being ICT literate and integrating ICTs in ELT in the context of Nepal. Keeping all these things in mind, this study aims to answer two research questions: how do English language teachers become ICT literate? and what are the purposes and challenges of integrating ICT in ELT?

\subsection{ICT and English Language Teaching: An Overview}

The use of technology in ELT perhaps started when English language teachers used tape recorders and cassettes to develop listening skills on the part of learners. Later on, with the advancement in science and technology different modern ICT devices were invented and they were used in education along with ELT. Stating the history, Acharya (2014, p. 3) writes; "Computer-based materials for language teaching, often referred as CALL (Computer Assisted Language Learning) appeared in the early 1980s including the activities like CDs, teaching computer programs, computer test, and encyclopedias." From this evidence, we can say that ICT is being used in ELT for decades. If we look at the ELT scenario around the globe along with our own Nepalese ELT scenario, we can find a vast change in the use of ICT in ELT from then to now. Several recent ICT innovations are being increasingly used in ELT. As the recent innovations, Mobile Assisted Language Learning (MAAL), Computer Assisted Language Learning (CALL), Technology Enhanced Learning (TELL), Blended Learning, and E-learning have been increasingly used in English language classrooms (Holmes \& Gardner, 2016).

ICT in education in general and ELT, in particular, have shifted the way of teaching-learning activities. English language learning and teaching methodologies have endured many changes over the last four decades: it has shifted from traditional grammar-translation methods to student-centered methods (Shrestha, 2011). This change has not only seen the shift in methodologies but also in the use of technologies/tools to teach the English language. It means along with the change in methods, the tools used in teaching-learning activities are changed. Gone are the days when the teachers based their teaching only on traditional methods and some materials like flashcards, word cards, and sentence cards. Instead of such materials, teachers make use and/or have to make use of different ICT devices like computers, laptops, interactive whiteboards, the internet, smartphones, TV, radios, and different applications like YouTube, social media, Google forms, Zoom, etc. these days. Overall, the $21^{\text {st }}$ century of teaching stresses the integration of ICT into all levels of education settings, especially in ELT (Hafifah, 2019).

ICT in ELT empowers both the teachers and students with several opportunities and choices that were not experienced before. In other words, the ICT integration in ELT has provided a host of opportunities to both the teachers and learners. It has been argued that "the teachers of English can take full advantage of technology to teach English in the nonnative speaking countries" (Pun, 2013, p. 31). ICTs help English teachers teach different language skills (listening, speaking, reading, and writing) and aspects (vocabulary and grammar) effectively to their students. Integration and utilization of ICT in ELT enhance students' English language competency and provide a positive learning environment (Raman \& Mohamed (2013).

Learners can easily be motivated and their curiosity towards learning is increased. In this line, Pazilah, Hashim, and Yunus (2019) state that technologies in the ESL classroom are the source of motivation and interest. As ICTs are interactive in nature, learners can interact and share their knowledge and help, fascinate and stimulate learners by making the classroom interesting and lively. In line with this Pun (2013) states that the use of multimedia technology motivates students to learn English, develops students' communicative competence, widens students' knowledge of English culture, improves teaching efficiency, enhances interaction among students and between teachers and students, creates a conducive teaching environment in the classrooms and provides opportunities for English teaching outside the classrooms. Moreover, learners' hesitation shyness and any difficulties which are considered hindrances of language learning can be removed by the amount of exposure provided by the use of ICT in ELT.

\subsection{Challenges of Integrating ICT in ELT}

Despite several advantages, the use of ICT in ELT is not free from challenges. The teachers who use ICT to facilitate their teaching-learning activities experience several ups and downs in course of using it. First and foremost, the teachers have to be ICT literate to make use of ICT in ELT. In this line, 
Hafifah, (2019, p.22) states, "Teachers are demanded to be ICT literate in dealing with tech-savvy students." Similarly, UNESCO's ICT Teacher Competency Standards Modules demand the basic hardware and software operations knowledge along with the knowledge of productivity applications software, a web browser, communications software, presentation software, and management applications on the part of teachers (UNESCO, 2014). Similarly, the Teacher Competency Framework (2016) takes ICT as one of the eight competency areas. Taking ICT as one of the competency areas, demands teachers to be competent to select and use instructional strategies with appropriate use of ICT, competent to design appropriate digital materials, and use them in teaching-learning activities and evaluation (National Centre for Educational Development [NCED], 2016). Using ICT in teaching-learning activities and being updated with ICTs is quite challenging to teachers in the initial days. The teachers who are not ICT friendly and/or ICT literate take being ICT literate as a challenge since they need to have their extra effort and time to be ICT literate.

Some challenges are caused due to the unavailability of infrastructures like electricity, ICT devices, internet facility, and financial hazards. Dhital (2018) mentions that lack of qualified teachers to teach ICT in schools, lack of electricity, problems related to policy, lack of computer (hardware and software resources), financial problems, and curricular-related problems as the challenges to use ICT in government school education of Nepal.

ICTs are just the means but not the ends. But these are taken as ends which have created problems/challenges to both the teachers and students. The use of ICTs lacks sufficient interaction between students and teachers. Moreover, some teachers face difficulty to keep their students on the right track in course of using ICTs in ELT. The technology sometimes gives restrictions to students' thinking potential and a student may distract and misuse the chance they get (Pazilah et al., 2019). Similarly, Shyamlee and Phil (2012) point out that major means replaced by the assisting one (i.e., the teachers may be turned into slaves to the multimedia and cannot play the leading role in teaching), loss of speaking communication, the restriction of students' thinking potential and abstract thinking replaced by imaginable thinking as the problems/challenges of the application of multimedia to English teaching.

Not all the schools, teachers, and students in developing countries like Nepal have the access to ICTs due to which a digital divide among schools, teachers, and students has been created. "The use of information and communications technology (ICT) for education in developing countries has been a subject of great interest and speculation, with its proponents arguing that ICT improves educational quality, develops critical thinking skills, expands access, increases economic competitiveness, and facilitates inclusion in a rapidly expanding global information society" (Shields, 2011, p. 1) but at the same time, it has created a digital divide. In the context of Nepal, not all schools, teachers, and students have the access to ICTs. Due to this fact, those who are in access are getting the chance to make use of ICT in ELT and they are benefiting. But those teachers and students who just have to rely on just blackboard, chalk, and duster as teaching materials are deprived of the benefits of ICTs. The divide is not only seen among the schools of the nation but also students of the same schools.

By these reviews, it is found that English language teachers make use of ICT for different purposes in their English classes on one hand and they face challenges to use ICT in ELT on the other. The purposes and challenges of ICT raised in this literature are general in nature. It means that they are not based on the real experience of teachers who make use of ICT in ELT. Therefore, this present study adds the purposes and challenges experienced by English language teachers in integrating ICT in ELT.

\section{Method}

This study is a phenomenological study that is based on the lived experience of secondary-level English language teachers who often make use of ICT in ELT. Defining phenomenology, Maruna and Butler (2005, p. 2) write; "Phenomenology... simply refers to the description and understanding of lived, human experience through observable forms of immediate cognitive experience and reflective analysis". The phenomenological approach is viewed as the highly appropriate means to research human experience (Wimpenny \& Gass, 2000) due to which this design was selected for this study.

To explore secondary level English language teachers' experience on the use of ICT in ELT, I selected two secondary level English language teachers teaching at public schools purposively as the participants. Phenomenological samples are nearly always purposive (Clark, 1998 as cited in Whitehead, 2002 p.499). One of the participants was from one of the public schools in Kathmandu, Nepal and the other was from one of the public schools in Lalitpur, Nepal. Since both of them have decade-plus experience in teaching the English language integrating ICT at the secondary level, they were selected for this study.

After informing the objectives and confidential nature of the study, both of the participants provided their verbal consent to take part in this study. After the consent, I arranged a time for interviews and took in-depth interviews from both of the participants in two different phases. In the first phase, both of the participants were interviewed and their interviews were audio-recorded taking their permission. I used the open-question 'funnel' technique while taking interviews. The 'funnel' technique of interview which 
was described by Cohen and Manion (1989), starts the interview process with general non-threatening questions that are designed to place the interviewee at ease in the initial stages and after the interviewee appears to have relaxed, the focus of further questions becomes more specific and knowledge-intensive (Whitehead, 2002). After transcribing the recorded interviews, I realized that some important points related to the experience of participants which were crucial to this study were missing. So, I arranged the next phase of interviews to include some more points related to the participants' experience. Then, I embedded the data gathered through the second phase in the interviews taken in the first phase.

The thematic analysis method was used to analyze data. This is a method for "identifying, analyzing and reporting patterns (themes) within data" (Braun \& Clarke, 2006, p. 79). Six phases of data analysis of thematic analysis as presented by Braun and Clarke (2006) were used to analyze the data and present the report of the themes. Accordingly, in the first phase, I transcribed all the interviews and became familiar with my data reading and re-reading them. Then, coding of data in a systematic fashion from both transcribes was done. In other words, I generated initial codes. After generating initial codes, I collated codes into potential three themes and their subthemes and gathered all data relevant to each potential theme and subthemes. Then, the themes were reviewed to make sure if the themes work. Finally, the themes were given names, and the report was produced. Though the interview was taken in the Nepali language, I translated myself the selected extracts to use them verbatim to clarify the themes. I tried my best to make the translation as accurate as possible.

\section{Findings and Discussion}

\subsection{Learning by Experiencing}

Different pieces of training, workshops, and formal classes help teachers to become ICT literate and use ICTs in teaching-learning activities effectively. As learning other different things, learning ICT is being a necessity to English language teachers these days. Some teachers learn ICTs with the help of their self-effort whereas some others take pieces of training provided by their institutions or any other related organizations.

In a query, how they became ICT literate, the participants of this study recalled their past and shared that they both had taken formal basic training which helped them to know the basic things like starting the computer, typing on it, creating files and folders, and saving them. Basic knowledge of surfing the internet was also given to them in the training. Such training helped them to be ICT literate. Regarding the experience on how he learned to operate the computer in his initial days, Rajendra (pseudonym) recalled;
I took a basic ICT class for three months in an institute that was near to my room. I learned to switch on and off the computer along with creating file folders and saving and transferring them [Rajendra, 20 ${ }^{\text {th }}$ December 2020].

This view suggests that taking formal classes and training is one of the ways to become ICT literate. Such class and training not only help to be ICT literate but also to make use of ICT in teachinglearning activities. In a study Rana, Greenwood, and Turnbull (2020) found that the participants of their study became ICT literate after they received a course (of varying length) in ICT training from the NGO which supported their schools with ICT infrastructure. Though no organization helped the participants of this study to become ICT literate, they learned ICT by taking formal class/training for three months on their effort. This finding partially matches with the finding of Rana et al. (2020).

Teachers' update on recent trends in ICT helps teachers make use of ICT effectively. To be updated, teachers take help of different means. This shows that being ICT literate does not work throughout one's career. In a query on how they become updated with ICTs, the participants of this study stated that they keep on taking different pieces of training and help of the one who is good at ICT. Rajendra, who gets knowledge on different ICT tools and their use in English language teaching via different means, shared his experience as;

There are several things that we have to learn on ICT since different new things are added. I learn such new practices especially with my colleagues who are experts and with the help of different training. I even talk with the teachers and friends in our teachers' professional development (TPD) pieces of training [Rajendra, $20^{\text {th }}$ December 2020].

This implies that learning is a continuous process. The knowledge on ICT that teachers have today becomes outdated tomorrow due to the changing nature of ICT. In other words, due to the advancement in science and technology, the knowledge that teachers have today becomes outdated tomorrow. In this line, the Teacher Competency Framework (2016) suggests teachers be updated themselves on the development of ICT (NCED, 2016). To be updated, teachers take the help of the experts of ICT or their colleagues who are good at ICT. Moreover, different refreshment pieces of training also help teachers be updated with the changing trend of ICT. Further, teachers get the knowledge of different ICT devices and their use in teaching-learning not only with the help of formal training and classes but also with the opportunities they get to have real exposure to it. In other words, some teachers have the experience of learning the use of different ICT devices due to the chance they get to teach. Surendra (pseudonym), who had to teach his students computer course in his 
school where there was no subject teacher of computer, struggled hard to learn and teach computer courses. He recalled his hardships that sometimes he had to spend hours learning the terminologies related to computers and the operation of different applications. He had to do so because the next day he had to teach his students effectively. Regarding this experience, he recalled;

Sir, as there is a well-known proverb in Nepali 'padhera vanda parera sikinchha' (meaning we learn more by experiencing than reading). When I got an appointment in a secondary school in Bhaktapur, Nepal no one except me knew to operate the computer. I had to teach a computer course which made me learn and be updated with ICT [Surendra, 25 ${ }^{\text {th }}$ December 2020].

This infers that the teachers better learn and become updated with ICT if they get a chance to teach some ICT-related courses. ICT Policy, 2015 states, "Steps will be taken to ensure that integration and deployment of ICTs in the education system will be adequately funded through government resources" (MoIaC, 2015, 12.2.1), unlike the essence of this line, a majority of community schools in Nepal lack ICT teachers due to which other teachers (English, Science and Maths teachers very often) have to teach some courses related to ICT. Teachers who are obliged to teach such courses, first learn different aspects of ICT for the effective delivery of subject matter. They not only teach their students but also learn simultaneously. This result shows that there is still a lack of teachers who can deal with ICT courses in public schools in Nepal. So, the stakeholders of education should take efforts to manage teachers who can teach ICT courses and scaffold other subject teachers in integrating ICT in education in public schools of Nepal.

From the experience shared by the participants of this study, it can be summarized that the nature of ICT, ICT devices used in teaching-learning, and activities keep on changing. The formal knowledge gained via different formal classes may not work equally throughout teachers' careers. Due to these changing phenomena, teachers need to be updated with such changing facts for the effective use of ICT in teaching-learning activities. For being updated with such changes secondary level English language teachers take different pieces of training, take support of experts and colleagues, learn with the help of different YouTube tutorials related to the subject matter and learn in course of teaching their students.

\subsection{ICT for Different Purposes}

Teachers make use of ICT in language classrooms for different purposes. Some use different ICT devices in the language classroom for entertainment and motivation and some others for language development on the parts of students and learner autonomy.
In a query of why and how they make use of ICT in English language teaching, the participants of this study shared that they make use of ICTs for different purposes. They also shared that their school administrator is supportive to manage different ICT tools needed in teaching-learning activities. The purposes of using ICT in English language teaching, are discussed and interpreted in the subsequent subthemes.

\subsubsection{ICT for Motivation and Fun}

ICTs play a significant role in motivating students. Different ICT devices are novel to our students due to which they become curious and motivated to learn the use of such devices along with learning English with such devices. It is the technology that plays a crucial role in bringing innovation and motivation for the learners (Stockwell, 2016). Supporting this line, the participants of this study make use of different motivational videos to motivate their students. Both of them shared that their students become happy and motivated when they inform their students that they are going to the computer lab for reading. Similarly, some other videos related to their subject matter are used to make students visualize the whole story or text. As Rajendra stated, "Visualization of such texts not only helps the students get real exposure on authentic language but also comprehend the text easily and develop their language" [Rajendra, $27^{\text {th }}$ December 2020; Follow up interview] Regarding this matter, Surendra shared;

Let me share my experience while teaching compulsory English of class eleven ... as you know there is a text named 'Worn Path'. We can find a video of the story which is of 25/30 min on youTube. By showing the video students can easily visualize the whole story and comprehend it more easily than we teach them in our class. Students are motivated [Surendra, $25^{\text {th }}$ December 2020].

Motivation helps the students to learn the subject matter with fun. As the participants shared their experiences, they make their students engage in different language-related games which help their students to learn a language with fun. Students engage themselves to be the winner in such games due to which in course of competing in such games they develop their language as the byproduct. Rajendra shared his experience as,

I make my students engage in games like 'Kon Banega karodpati' (meaning who becomes a millionaire?) hosted by Amitab Bachan (famous Indian actor) using quizzes.com. I prepare questions from the previously discussed content. They get marks on correct answers which makes them motivated. They feel like a competition. [...] They develop their language with fun [Rajendra, 20th December 2020]. 
From the experience shared by the participants, what can be said is the use of ICT in English language teaching arouses motivation and fun on the part of students. It is the teacher's job to motivate their students using ICTs and "motivated students will be more likely to perform at their highest levels because of the opportunities that their teachers have made available" (Joshi \& Paudel, 2019, p. 69). Different language games which are designed to teach language skills are not only effective to teach language but also equally effective to create motivation and fun on the part of students.

\subsubsection{ICT for Language Development}

ICT is used for language development. To develop different language skills and aspects, teachers make use of different ICT tools and applications. Some modern electronic devices such as computers, television, mobile phone, multimedia, and web-based applications have played vital roles in language teaching (Joshi \& Paudel, 2019). Tabs, laptop, mobile set, smartboard, computer lab, YouTube, PowerPoint, Google docs, Google forms, and other different websites are some common ICT tools and applications often used to teach different language skills and aspects to the students. While having a query which ICT devices are often used and why Surendra shared;

As an ICT tool, I often use mobile. Sometimes I save something important on my mobile and show it to my students. These days, I use a computer, laptop, PowerPoint projector, and smartboard to teach different skills and aspects to my students [Surendra, 28 ${ }^{\text {th }}$ December 2020; Follow up interview].

Rajendra also shared a similar type of experience,

I use YouTube to teach different vocabulary and grammar along with other different skills. As you know sir, these days we find a great deal of stuff on YouTube which is very much helpful to teach different aspects and skills to our students [Rajendra, 20 ${ }^{\text {th }}$ December 2020].

The experience shared by both of the participants reveals that different ICT devices can be used to teach different language skills and aspects on the part of our students. Technology is remarkably significant for the teaching of all aspects and skills of language (Sharma, 2012). Teachers feel easier to teach language using different ICT devices in comparison to the traditional way (i.e. without integrating ICTs) and students learn easily. ICT can be used to integrate listening, speaking, reading, and writing skills (Ghasemi \& Hashemi, 2011).

\subsubsection{ICT for Learner Autonomy}

The use of ICT in English language teaching has promoted learner autonomy as it has been replacing traditional one-way traffic methods. Holec (1981 as cited in Xhaferi \& Xhaferi, 2011, p. 150) defines learner autonomy as "the ability to take charge of one's learning." ICTs have not only made English teachers shift their way of teaching but also have made students autonomous. The students engage in different activities actively when teachers make use of ICT in English language teaching. The students can do it on their own just with little or no facilitation from their teachers both in and outside the classroom. The participants of this study shared how ICTs have promoted learner autonomy in an inquiry on why they make use of ICTs in English language classrooms. They even shared that some of the students in their classes are better than them who can guide their friends easily. Regarding this line, Surendra shared;

ICT has promoted learner autonomy. Students learn on their own if we just guide them. Let me share my one incident. Once, I assigned project work to take an interview with a local business person to my students. They took the interview, recorded it, transcribed it, translated and finally, made a report and submitted me along with the recorded interview on their pen drive [Surendra, $25^{\text {th }}$ December 2020].

Rajendra also shared a similar type of experience. He mentioned,

Some of the students of this era are far better than us in ICT. Such students become teachers are some cases. They not only learn themselves but also teach their friends. They can learn on their own even in the absence of teachers [Rajendra, $20^{\text {th }}$ December 2020].

This result advocates the use of ICT for learner autonomy. ICT helps teachers to promote learner autonomy. ICT supports autonomy because it provides greater freedom and flexibility to learn at one's own pace and convenience (Ghasemi \& Hashemi, 2011). Traditional educational practices no longer provide skills to students to be independent in learning due to which learner autonomy and learner independence can be sought in the classroom through the integration of ICTs (Joshi \& Paudel, 2019). Similar to this result, Rana et al. (2020) found that teachers had shifted their teaching to student-centered from teacher-centered due to the use of ICT. The shift in teaching strategies from traditional methods to student-centered is caused due to the use of ICT in the classroom. It has not only helped teachers to shift their teaching strategies/methods but also promote learner autonomy.

From the experience shared by the participants of this study, what can be said is the use of ICT in ELT has helped teachers to manage time, promote learner autonomy, develop language skills, and motivate students. It shows that the integration of ICT in the teaching and learning process brings about powerful learning environments which help students to deal with knowledge in active, creative, and self-directed 
ways (Bhusal, 2020). Furthermore, it has helped teachers to feel that teaching is an easy job if they make use of ICT in teaching-learning activities.

\subsection{Derailing the Track}

Along with the opportunities as discussed above, the use of ICT in ELT has several challenges too. It means despite several benefits; the use of ICT in English language teaching is not free from challenges. In a query on the challenges that they face using ICT, both of the participants stated some common challenges like power cut, unavailability of some tools, large classes, the problem of devices maintenance, and protection of ICT tools. Such challenges as the participants stated are caused by students, school, their knowledge, and sometimes their coworkers. But to be specific, they experience the misuse of ICT by the students in the course of teaching-learning activities. They shared that students often misuse or derail from their track if they are not monitored well. Supporting this line, Surendra stated; "What happens is when I ask the students to be engaged in different activities providing them some guidelines for their language development, the students misuse the devices and time and engage themselves in some other personal affairs of their interest" [Surendra, 28 ${ }^{\text {th }}$ December 2020; Follow up interview] In this line, Rajendra shared;

Our students of secondary level are teenagers. Due to their age, they do have different curiosity mmm when we use ICT they misuse the chance... they watch things that are of their interest especially when there is no monitoring [Rajendra, $20^{\text {th }}$ December 2020].

This suggests that some of the challenges that the teachers face are caused due to the lack and weak management of infrastructures in schools. In this regard, Rana et al. (2020) found that the teachers have experienced barriers to integrating ICT in education due to the barriers like unavailability of the internet, school's financial problems, and expensive mobile data. Similarly, Hashemi and Kew (2021) found a lack of teachers' confidence in using technology, lack of effective training, and lack of time as the challenges of integrating ICT in ELT.

Though both of the participants of this study do not experience as the participants of Rana et.al. (2020)'s study since they both are from wellfacilitated schools of Kathmandu valley, they are not free from the challenges/ barriers. Leaving the track is one of the major challenges that the participants of this study experience when they integrate ICT in English language teaching. Students derail the tracks due to some factors like their age, motivation, interest, and type of subject matter that they are asked to be engaged in. Some students are likely to leave the track due to the lack of sufficient knowledge on operating ICT devices. The students should be monitored and facilitated effectively to make sure that they are on the right track and they are learning via ICTs as Surendra stated.

\section{Conclusions}

ICT is perhaps the most talked-about phenomenon in teaching-learning activities these days. As it has impacts on other different sectors, it has a great impact on teaching-learning too due to which it is widely used in our classes. Being ICT literate for integrating it in teaching-learning is a great need for every teacher. As the findings of this study reveal, teachers become ICT literate and are updated with the changing trends of ICT via different formal and professional platforms like training, teacher support groups, and classes. Moreover, they learn by experiencing i.e., the chance they get to teach some ICT-related course. After being ICT literate, teachers make use of ICT for different purposes in their classes. The purposes vary based on the nature of the subject matter they are dealing with. The main purpose of using ICT in English language classes is for language development, learner autonomy, and motivation. The learners are motivated if they are exposed to different ICTs. As a result, they can develop different language skills and aspects on their own. No doubt, ICT has several advantages; it is not free from challenges too. The teachers who make use of ICT in English language teaching have different challenges. Some of the challenges are caused due to unavailability of infrastructures and some others are caused by students. The students due to their age factor misuse ICTs and derail their track if the teachers make use of ICTs in the language classroom. However, this challenge can be solved by monitoring the students effectively either by the teacher himself/herself or by class/ group monitor.

The teachers who have not been using ICT due to different factors should be encouraged to clarify the concept that using ICT is not a burden rather ease. The teachers who are not ICT literate should be given literacy training and those who are literate should be given refreshment training to make them updated with the recent trends of ICT. For this, teacher professional development (TPD) training provided by NCED and other related agencies should incorporate ICT-related subject matter. Moreover, the policies and documents related to ICT should function as per their essence to integrate ICT in education. Finally, teachers should try their utmost to use ICT in education in general and English language teaching in particular leaving their unnecessary pretends. This study due to its limitations touched the base on secondary level English language teachers' experience on being ICT literate, purposes of using ICT along challenges they face in course of teaching English language using ICT. There are still several areas like students' experience on ICT, solutions that teachers adapt to overcome the challenges, school administrators' view and management on ICT, and like which need further studies for their exploration. 


\section{References}

Acharya, C. P. (2014). Use of ICT/ web tools in ELT in Nepal. Journal of NELTA, 19 (1-2), 1-16. https://doi.org/10.3126/nelta.v19i1-2.12076

Bhusal, D. R. (2020). Nepalese Teachers' Perceptions on Integrating Technology in English Language Teaching. English Language Teaching and Research, 2(2), 19-25. http://dx.doi.org/10.33474/eltar-j.v2i2.8552

Braun, V. \& Clarke, V. (2006). Using thematic analysis in psychology. Qualitative Research in Psychology, 3(2), 77-101.

Dhital, H. (2018). Opportunities and challenges to use ICT in government school education of Nepal. International Journal of Innovative Research in Computer and Communication Engineering, 6(4), 3215-3220 http://dx.doi.org/10.15680/IJIRCCE.2018.06040 04

Ghasemi, B. \& Hashemi, M. (2011). ICT: Newwave in English language learning/teaching. Procedia Social and Behavioral Sciences, 15, 3098-3102. http://dx.doi.org/10.1016/j.sbspro.2011.04.252

Hafifah, G.N. (2019). Information and Communication Technology (ICT) in English Language Teaching. Proceedings of MELTC (Muhammadiyah English Language Teaching Conference), 21-38. University of Muhammadiyah Surabaya. http://103.114.35.30/index.php/Pro/article/view/ 2999

Hashemi, A. \& Kew, S.N. (2021). The barriers to the use of ICT in English language teaching: A systematic literature review. Journal of Information and Communication Technologies, 3(1), 77-88.

Holmes, B. \& Gardner, J. (2016). E-learning: Concepts and practice. Sage.

Joshi, K., \& Paudel, G.P. (2019). Role of ICTs in promoting learner independence and motivation in English language classes. Interdisciplinary Research in Education, 4 (1), 67-76.

Maruna, S., \& Butler, M. (2005). Phenomenology. In K. Kempf-Leonard (Ed.), Encyclopedia of Social Measurement, 3, 49-52. doi: 10.1016/B0-12369398-5/00563-6

Ministry of Education. (2016). School sector development plan, Nepal, 2016-2023. https://www.globalpartnership.org/content/nepal -school-sector-development-plan-2016-2023

Ministry of Information and Communication, Government of Nepal. (2015). National information and communication technology policy, 2015. https://ictframe.com/ict-policy2015-of-nepal-initiatives/

National Planning Commission, Government of Nepal. (2019). 15th plan. https://nepaleconomicforum.org/neftake/keyhighlights-from-nepals-long-term-economicvision-fy2020-fy2044-and-nepals-15th-fiveyear-plan-fy2020-fy2024/

Pazilah, F. N., Hashim, H., \& Yunus, M. Md. (2019). Using Technology in ESL Classroom: Highlights and Challenges. Creative Education, 10 , 3205-3212. https://doi.org/10.4236/ce.2019.1012244

Poudel, P.P. (2015). Information and communication technologies and teacher educators of English in Nepal. Journal of NELTA, 20 (1-2), 27-33.

Pun, M. (2013). The use of multimedia technology in English language teaching: A global perspective. Crossing the Border: International Journal of Interdisciplinary Studies, 1(1), 29-38.

Raman, A. \& Mohamed, A. H. (2013). Issues of ICT usage among Malaysian secondary school English teachers. English Language Teaching, 6 (9), 74-82. doi:10.5539/elt.v6n9p74

Rana, K., Greenwood, J., \& Turnbull, W. (2020). Implementation of Nepal's education policy in ICT: Examining current practice through an ecological mode. E J Info Sys Dev Countries. 86 (2), 1-16. https://doi.org/10.1002/isd2.12118

Sharma, B. (2012). Readings in advanced English language teaching methodology. Sunlight Publication.

Shields, R. (2011). ICT or I see tea? Modernity, technology and education in Nepal. Globalisation, Societies and Education, 9(1), 8597.

https://doi.org/10.1080/14767724.2010.513536

Shrestha, P. (2011). The potential of mobile technologies for English language learning in Nepal. Journal of NELTA, 16, 107-112.

Shyamlee, S. D., \& Phil, M. (2012). Use of technology in English language teaching and learning: An analysis. Proceeding International Conference on Language, Medias and Culture, 33, 150-156.

Stockwell, G. (2012d). Computer assisted language learning diversity in research and practice. Cambridge University Press.

UNESCO. (2008). ICT competency standards for teachers. https://en.unesco.org/themes/icteducation/competency-framework-teachers

UNESCO. (2014). Information and communication technology (ICT) in education in Asia. 
http://uis.unesco.org/en/topic/information-andcommunication-technologies-ict

Whitehead, D. (2002). The academic writing experiences of a group of student nurses: A phenomenological study. Journal of Advanced Nursing 38(5), 498-506. https://doi.org/10.1046/j.13652648.2002.02211.x

Wimpenny P. \& Gass J. (2000). Interviewing in phenomenology and grounded theory: Is there a difference? Journal of Advanced Nursing 31, 1485-1492. https://doi.org/10.1046/j.13652648.2000.01431.x

Xhaferi , B., \& Xhaferi, G. (2011). Developing learner autonomy in higher education in Macedonia. Procedia Social and Behavioral Sciences, $11, \quad 150-154$. https://doi.org/10.1016/j.sbspro.2011.01.051 